DR MADDALENA MORLANDO (Orcid ID : 0000-0002-1304-7575)

DR DANILO BUCA (Orcid ID : 0000-0001-6880-7407)

PROFESSOR ILAN TIMOR-TRITSCH (Orcid ID : 0000-0001-9774-3107)

PROFESSOR JOSE M PALACIOS-JARAQUEMADA (Orcid ID : 0000-0002-5240-5320)

Article type : Systematic review

\title{
Reproductive outcome after cesarean scar pregnancy: A systematic review and
} meta-analysis

Maddalena Morlando ${ }^{1}$, Danilo Buca ${ }^{2}$, Ilan Timor-Tritsch ${ }^{3}$, Giuseppe Cali ${ }^{4,5}$, Jose PalaciosJaraquemada $^{6}$, Ana Monteagudo ${ }^{7}$, Asma Khalil ${ }^{8}$, Carmen Cennamo ${ }^{1}$, Viviana La Manna ${ }^{1}$, Marco Liberati ${ }^{2}$, Alice D'Amico ${ }^{2}$, Luigi Nappi ${ }^{9}$, Nicola Colacurci ${ }^{1}$, Francesco D'Antonio ${ }^{2}$

1: Department of Woman, Child and General and Special Surgery, University of Campania "Luigi Vanvitelli", Naples, Italy

2: Centre for High Risk Pregnancy and Fetal Care, Department of Obstetrics and Gynecology, University of Chieti, Chieti, Italy

3: Department of Obstetrics and Gynecology, Division of Maternal-Fetal Medicine, New York University SOM, New York, NY, USA

4: Department of Obstetrics and Gynecology, Azienda Ospedaliera Villa Sofia Cervello, Palermo, Italy 5: Department of Obstetrics and Gynecology, Arnas Civico Hospital, Palermo, Italy

6: Centre for Medical Education and Clinical Research (CEMIC), University Hospital, Buenos Aires, Argentina

7: Department of Obstetrics, Gynecology and Reproductive Science, Icahn School of Medicine at Mount Sinai, New York, NY, USA

This article has been accepted for publication and undergone full peer review but has not been through the copyediting, typesetting, pagination and proofreading process, which may lead to differences between this version and the Version of Record. Please cite this article as doi: 10.1111/AOGS.13918

This article is protected by copyright. All rights reserved 
8: Fetal Medicine Unit, St George's Hospital, London, UK

9: Fetal Medicine Unit, Department of Medical and Surgical Sciences, Department of

Obstetrics and Gynecology, University of Foggia, Foggia, Italy

\section{Corresponding Author:}

Francesco D'Antonio

Department of Obstetrics and Gynecology, Centre for High Risk Pregnancy and Fetal Care University of Chieti, Via dei Vestini 66100 Chieti, Italy

Email: francesco.dantonio@unifg.it

\section{Conflict of Interest}

None

This article is protected by copyright. All rights reserved 


\section{ABSTRACT}

Introduction: To evaluate subsequent reproductive among women with a prior cesarean scar pregnancy (CSP). Material and methods: Medline, Embase and ClinicalTrials.gov databases were searched. Inclusion criteria were women with a prior CSP, defined as the gestational sac or trophoblast within the dehiscence/niche of the previous cesarean section scar or implanted on top of it. The primary outcome was the recurrence of CSP; secondary outcomes were the chance of achieving a pregnancy after CSP, miscarriage, preterm birth, uterine rupture and the occurrence of placenta accreta spectrum disorders. Sub-group analysis according to the management of CSP (surgical vs non- surgical) was also performed. Random effect meta-analyses of proportions were used to analyze the data. Results: Forty-four studies (3598 women with CSP) were included. CSP recurred in $17.6 \%$ of women. Miscarriage, preterm birth and placenta accreta spectrum disorders complicated $19.1 \%$ (65/341), $10.3 \%$ (25/243) and $4.0 \%$ of pregnancies, while $67.0 \%$ were uncomplicated. When stratifying the analysis according to the type of management, CSP recurred in $21 \%$ of women undergoing surgical and in $15.2 \%$ of those undergoing non-surgical management, while placenta accreta spectrum disorders complicated $4.0 \%$ and $12.0 \%$ of cases respectively. Conclusions: Women with a prior CSP are at high risk of recurrence, miscarriage, preterm birth and placenta accreta spectrum. There is still insufficient evidence to elucidate whether the type of management adopted (surgical vs non-surgical) can impact reproductive outcome after CSP. Further large prospective studies sharing an objective protocol of prenatal management and long-term follow up are needed to establish the optimal management of CSP and to elucidate whether it may affect its risk of recurrence and pregnancy outcome in subsequent gestations.

\section{KEY WORDS}

Cesarean scar pregnancy, placenta accreta spectrum, reproductive outcome, surgical treatment, preterm birth, uterine rupture.

\section{ABBREVIATIONS}

CSP: cesarean scar pregnancy 
PAS: placenta accreta spectrum

CS: cesarean section

\section{KEY MESSAGE}

Women with a prior cesarean scar pregnancy are at high risk of recurrence of cesarean scar pregnacy, miscarriage, preterm birth and placenta accreta spectrum.

This article is protected by copyright. All rights reserved 


\section{INTRODUCTION}

Cesarean scar pregnancy (CSP) is one of the most severe complications of cesarean delivery, with a reported incidence of 1.2000 pregnancies ${ }^{1}$. CSP refers to the implantation of the gestational sac in the area of the prior cesarean section (CS) scar, which may lead to severe haemorrhage, uterine rupture and hysterectomy. More recently, CSP has been linked with the occurrence of placenta accreta spectrum (PAS) disorders. 1-6

Prenatal diagnosis of CSP is fundamental because it allows a pre-planned treatment in centres with high expertise in the management of such anomalies. Prenatal diagnosis of CSP is commonly accomplished on ultrasound and is based upon the visualization of the gestational sac within the area of the prior CS scar, in the presence of an empty uterine cavity and a thin myometrium. $1,4,7,8$

The natural history of CSP is unpredictable as it can lead to life-threatening conditions in early pregnancy, including uterine rupture and haemorrhage, or evolve towards PAS in the third trimester of pregnancy. Several management options for CSP, either surgical or non-surgical, have been described but there is high heterogeneity in the reported results. Furthermore, there is also a lack of consistent data on the reproductive outcome after a prior CSP. Small sample size of previously published studies, inclusion of cases with different types of management and heterogeneity of outcomes explored do not allow to extrapolate an objective evidence on the actual risk of adverse outcome in women after a prior CSP 9-11.

The primary aim of this systematic review was to evaluate subsequent reproductive among women with a prior CSP; the secondary aim was to elucidate whether the type of treatment (surgical vs non- surgical) may affect the reproductive and pregnancy outcome of women with a prior CSP.

\section{MATERIAL AND METHODS}

This review was performed according to a protocol designed a priori and recommended for systematic review. Medline, Embase and ClinicalTrials.gov databases were searched electronically on 01/12 2019 utilizing combinations of the relevant medical subject heading

This article is protected by copyright. All rights reserved 
(MeSH) terms, key words, and word variants for "cesarean scar pregnancy" and "outcome."

Reference lists of relevant articles and reviews were hand searched for additional reports.

PRISMA guidelines were followed 12,13 .

Inclusion criteria were women with a prior CSP, defined as the gestational sac or trophoblast within the dehiscence/niche of the previous CS scar or implanted on top of it and diagnosed according to the following criteria 14 .

1. Visualization of an empty uterine cavity.

2. Detection of the placenta and/or a gestational sac embedded in the hysterotomy scar.

3. A triangular gestational sac that fills the niche of the scar.

4. A thin (1-3 mm) or absent myometrial layer between the gestational sac and the bladder.

5. A closed cervix and empty endocervical canal.

6. The presence of embryonic/fetal pole and/or yolk sac with or without heart activity.

7. The presence of a prominent and at times rich vascular pattern at or around the choronic sac and the placenta

The primary outcome was the recurrence of CSP, defined as the occurrence of a new CSP. Secondary outcomes were:

1. The chance of achieving a new pregnancy after CSP, defined as the presence of at least a positive pregnancy test in women wishing to conceive.

2. Intra-uterine pregnancy following a prior CSP.

3. Ectopic pregnancy after a prior CSP.

4. Miscarriage, defined as intra-uterine loss of the expulsion of the product of conception before 20 weeks of gestation.

5. Preterm birth, defined as birth before 37 weeks of gestation.

6. Uterine rupture

7. Occurrence of PAS disorders

8. Uncomplicated pregnancies, defined as the number of pregnancies not experiencing major surgical complications. 
Furthermore, we aimed to perform a sub-group analysis reporting all the explored outcomes according to the type (surgical vs non-surgical) treatment of the CSP. Surgical treatment included uterine curettage, hysteroscopy, laparotomic or laparoscopic resection, while nonsurgical treatments included systematic administration of methotrexate, local injection of methotrexate of potassium chloride in the gestational sac, needle aspiration, high intensity focused ultrasound, Foley or Cook's catheter insertion or uterine artery embolization. The reproductive outcome after CSP was computed only in women who wished to achieved pregnancy, while pregnancy outcome was ascertained in those with a confirmed intra-uterine pregnancy.

Only studies reporting the reproductive outcome of pregnancy with a prior CSP were considered eligible for the inclusion. Studies reporting only symptomatic women and those for which diagnosis of CSP was not clearly described were excluded (Supporting Information Table S1). Only full text articles were considered eligible for the inclusion. Conference abstracts and single case reports were excluded to avoid publication bias. Studies published before 2000 were not included, as we considered that advances in prenatal imaging techniques, improvements in the diagnosis and management of CSP make these less relevant.

Two authors (DB, FDA) reviewed all abstracts independently. Full text copies of those articles were obtained, and the same two reviewers independently extracted relevant data regarding study characteristics and pregnancy outcome. Inconsistencies were discussed and consensus was reached, or the dispute was resolved by discussion with another author. If more than one study was published for the same cohort with identical endpoints, the report containing the most comprehensive information on the population was included to avoid overlapping populations. Quality assessment of the included studies was performed using the NewcastleOttawa Scale (NOS) for cohort studies ${ }^{15}$. According to Newcastle-Ottawa Scale, each study is judged on three broad perspectives: the selection of the study groups; the comparability of the groups; and the ascertainment outcome of interest. Assessment of the selection of a study includes the evaluation of the representativeness of the exposed cohort, selection of the nonexposed cohort, ascertainment of exposure and the demonstration that outcome of interest was not present at start of study. Assessment of the comparability of the study includes the evaluation of the comparability of cohorts on the basis of the design or analysis. Finally, the ascertainment of the outcome of interest includes the evaluation of the type of the assessment of the outcome 
of interest, length and adequacy of follow-up. According to Newcastle-Ottawa Scale, a study can be awarded a maximum of one star for each numbered item within the Selection and Outcome categories. A maximum of two stars can be given for Comparability (http://www.ohri.ca/programs/clinical_epidemiology/oxford.asp)

We used random-effect meta-analyses of proportions using random effects model were used to combine data ${ }^{16}$. Funnel plots displaying the outcome rate from individual studies versus their precision (1/standard error) were carried out with an exploratory aim. Tests for funnel plot asymmetry were not used when the total number of publications included for each outcome was less than ten. In this case, the power of the tests is too low to distinguish chance from real asymmetry 17,18 . Between- study heterogeneity was explored using the $\mathrm{I}^{2}$ statistic, which represents the percentage of between- study variation that is due to heterogeneity rather than chance. ${ }^{19}$ As previously described ${ }^{62}$, we constructed a hypothetical model with 1000 women with a prior CSP treated medically or surgically wanting to achieve a subsequent pregnancy.

\section{RESULTS}

\section{Study selection and characteristics}

A total of 358 articles were identified, 122 were assessed with respect to their eligibility for inclusion and 44 studies included in the systematic review (Table 1, Figure 1)9,10,20-60. These studies included 3598 women with a prior CSP; out of these, information on subsequent pregnancy was available for 592 women.

Quality assessment of the included studies performed using Newcastle-Ottawa Scale ${ }^{15}$ for cohort studies is shown in Table 2. Most of the included studies showed an overall good rate about the selection and comparability of the study groups. The main weaknesses of these studies were their retrospective design, small sample size, lack of stratification of the analysis according to type of treatment adopted (surgical vs non-surgical), gestational age at intervention and heterogeneity of outcomes observed.

CSP recurred in $17.6 \%$ (95\% CI 4.6-20.8; 107/618) of cases, while $82.6 \%$ (95\% CI $79.3-$ 
$85.5 ; 503 / 618$ ) of women had an intra-uterine pregnancy (Table 3, Figure 2). Eighteen studies (300 women) reported the reproductive outcome after a prior CSP; among women who wished to conceive, pregnancy was achieved in $70.6 \%$ (95\% CI 66.0-74.9) of cases.

In women experiencing an intra-uterine pregnancy after a prior CSP, the rate of uterine rupture was $1.5 \%$ (95\% CI 0.5-3.4; 5/341), while miscarriage, preterm birth and PAS disorders complicated 19.1\% (95\% CI 15.0-23.6; 65/341), 10.3\% (95\% CI 6.8-14.8; 25/243) and 4.0\% (95\% CI 2.1-6.7; 13/327) of pregnancies. Finally, 67.0\% (95\% CI 61.6-72.0; 219/327) of the included cases had an uncomplicated pregnancy (Table 3).

Sub-group analysis according to the type of management adopted (surgical vs nonsurgical) was affected by the small number of included cases and even smaller number of events. CSP recurred in 21.0\% (95\% CI 17.3-25.2; 90/428) of women undergoing surgical and in $15.2 \%$ (95\% CI 9.7-22.4; 21/138) of those undergoing non-surgical treatment, while the corresponding figures for the chance of achieving pregnancy were $74.4 \%$ (95\% CI 69.3-79.0; $244 / 428)$ and $68.7 \%$ (95\% CI 56.2-79.4; 46/67) respectively (Table 4).

Miscarriage and preterm birth complicated 16.2\% (95\% CI 11.8-21.6; 38/234) and 8.9\% (95\% CI 5.0-14.5; 14/157) of women undergoing surgical compared to $14.7 \%$ (95\% CI 7.3 $25.4 ; 14 / 68)$ and $15.2 \%$ (95\% CI 7.5-26.1; 10/66) of those undergoing-non-surgical management.

Finally, 2.7\% (95\% CI 1.0-5.8; 6/221) of pregnancies undergoing surgical and 10.6\% (95\% CI 4.4- 20.6; 7/66) of those undergoing non-surgical treatment of the prior CSP experienced PAS disorders in the subsequent pregnancy.

In a hypothetical model (Figure 3) of 1000 women with a prior CSP treated medically or surgically wanting to achieve a subsequent pregnancy, $70 \%$ of those wanting to conceive, will achieve a pregnancy. Among these, $18 \%$ will experience a recurrence of CSP, while $82 \%$ will obtain a intrauterine pregnancy. In the group of women with intrauterine pregnancy, the $19 \%$ will have a miscarriage, the $10 \%$ will experience a preterm birth, and the $4 \%$ will result in PASat delivery. The $67 \%$ will have an uncomplicated pregnancy resulting in livebirth at term.

\section{DISCUSSION}

The findings from this systematic review show that, in women with a prior CSP, the risk of

This article is protected by copyright. All rights reserved 
recurrence is about $17 \% .70 \%$ of women who wished to conceive again achieved a pregnancy. Miscarriage and preterm birth complicated about $19 \%$ and $10 \%$ of pregnancies, while PAS disorders occurred in $4 \%$ of cases. Finally, $67 \%$ of women had an uncomplicated pregnancy. In view of the small number of included studies, lack of direct comparison in the original publication and heterogeneity in outcomes observed and management options, it was not possible to fully elucidate whether the type of treatment of CSP (surgical vs non-surgical) affected the explored outcomes.

To our knowledge, this is the first systematic review assessing the reproductive and pregnancy outcome of women with a prior CSP. A recent systematic review exploring the longterm risk associated with $\mathrm{CS}$, reported a higher risk of miscarriage, placenta accreta and placental abruption in women having cesarean compared to vaginal delivery 61 . In the present review, we could not compare the risk of the explored outcome in pregnancies affected compared to those not affected by a prior CSP because there was no case-control study reporting these outcomes. However, the occurrence of CSP, uterine rupture and PAS in women with a prior CSP were higher compared to what reported for women with a previous $\mathrm{CS}^{1}$. The small number of cases in the majority of the included studies, their retrospective nonrandomized design, lack of stratification of the analysis according to the type of management adopted (surgical vs non-surgical) and heterogeneity in gestational age at treatment for most of the included studies represent the main weaknesses of the present systematic review. The assessment of the potential publication bias was also problematic, both because of the nature of outcome (rates with the left side limited to the value zero) which limits the reliability of funnel plots, and because of the scarce number of individual studies, which strongly limits the reliability of formal tests. The level of evidence for these types of studies is very low.

CSP and PAS disorders are among the most severe iatrogenic complications of cesarean delivery. There is still no adequately powered randomized controlled trial on the optimal treatment of CSP. Previously published studies differ as regard as gestational age at diagnosis and treatment, type of management (surgical vs non-surgical) and outcomes explored, thus making difficult to extrapolate an objective evidence on how to treat these anomalies 9-11. Reproductive outcome of women with a prior CSP is another relevant issue and it has still to be fully ascertained how to counsel these women. Surgical treatment of CSP may affect the integrity of the anterior uterine wall and may sometimes end-up in unplanned hysterectomy, 
especially in those cases presenting with severe life-threatening symptoms, thus affecting the future fertility of these women. Conversely, non-surgical treatment may lead to the incomplete removal of the CSP and the persistence of the cesarean scar, thus predisposing to a recurrent CSP 1-5 In the present systematic review, 17\% of women with a prior CSP , this anomaly recurred, thus highlighting the need for an early ultrasound assessment during the first trimester of pregnancy in order to rule out CSP. Predicting the risk of adverse pregnancy outcome in women after CSP is also challenging. Women with CSP are at increased risk of uterine rupture and PAS, due to the anatomical weakness of the myometrium and the presence of a prior scar. This may partially explain the high incidence of uterine rupture and PAS observed in women pregnancies affected by a prior CSP and highlights the need for a thorough follow-up thorough pregnancy in order to timely detect these anomalies. ${ }^{1-5}$

The optimal management of CSP has still to be determined as there is no evidence form randomized controlled trials. Different treatment options for CSP, either surgical or non-surgical have been reported in the published literature, but there is still lack of data on short and long-term complications following treatment $9-11$.

In the present review, CSP recurred in $21.0 \%$ (of women undergoing surgical and in $15.2 \%$ of those undergoing non-surgical treatment, although a direct comparison could not be performed in view of the original design of the included studies. Uterine rupture $(0.9 \%$ vs $4.4 \%)$ and PAS disorders $(2.7 \%$ vs $10.6 \%)$ were relatively more common in women undergoing nonsurgical compared to surgical management of PAS. A possible explanation for these discrepancies may rely on the fact that surgical treatment of CSP can partially restore the anatomy of the anterior uterine wall. Conversely, in non- surgical treatment, the persistence of the area of the prior CS scar, especially in cases presenting with a large niche, may predispose to further CSP or adverse events related to the thin myometrium over the area of the prior scar. However, this data should be interpreted with caution as none of the included studies was designed to compare different treatment modalities and it is entirely possible that other cofactors, such as gestational age at treatment, size of the prior scar and CSP may have affected the results. Furthermore, these sub-analyses were affected by the very small number of cases and even smaller number of events, thus representing a significant source of bias and highlighting the need for further studies aimed at exploring the short- and long-term consequences of the different treatment modalities for CSP.

This article is protected by copyright. All rights reserved 


\section{CONCLUSION}

Women with a prior CSP should be counselled on the high risk of recurrence of CSP, uterine rupture and PAS disorders in a subsequent pregnancy. In view of the original study design, it was not possible to elucidate whether the type of management adopted (surgical vs non-surgical) may affect reproductive outcome after CSP. Further large prospective studies sharing an objective protocol of prenatal management and long-term follow-up are needed in order to establish the optimal type of management of CSP and to elucidate whether it may affect pregnancy outcome in subsequent gestations.

\section{ACKNOWLEDGEMENT}

We would like to thank Dr. Y-C Chiang for the additional data provided and support. 


\section{REFERENCES}

1. Timor-Tritsch IE, Monteagudo A. Unforeseen consequences of the increasing rate of cesarean deliveries: early placenta accreta and cesarean scar pregnancy. A review. Am J Obstet Gynecol. 2012; 207:14-29.

2. D'Antonio F, Palacios-Jaraquemada J, Lim PS, al Counseling in fetal medicine: evidence-based answers to clinical questions on morbidly adherent placenta. Ultrasound Obstet Gynecol 2016;47: 290-301.

3. Cali G, Timor-Tritsch I, Forlani F, et al. Value of first-trimester ultrasound in prediction of third-trimester sonographic stage of placenta accreta spectrum disorder and surgical outcome. Ultrasound Obstet Gynecol. 2020;55:450-459.

4. Cali G, Forlani F, Minneci G, et al. First trimester prediction of surgical outcome in abnormal invasive placenta using the cross-over sign. Ultrasound Obstet Gynecol 2018; 51:184-8.

5. Cali G, Forlani F, Timor-Trisch I, Palacios-Jaraquemada J, Minneci G, D'Antonio F. Natural history of cesarean scar pregnancy on prenatal ultrasound: the cross-over sign. Ultrasound Obstet Gynecol 2017;50:100-4.

6. Calì G, Timor-Tritsch IE, Palacios-Jaraquemada J, etal. Outcome of Cesarean scar pregnancy managed expectantly: systematic review and meta- analysis. Ultrasound Obstet Gynecol. 2018;51:169-75.

7. D'Antonio F, Timor-Tritsch IE, Palacios-Jaraquemada J, et al. First-trimester detection of abnormally invasive placenta in high-risk women: systematic review and meta-analysis. Ultrasound Obstet Gynecol. 2018;51:176-83

8. Iacovelli A, Liberati M, Khalil A, et al. Risk factors for abnormally invasive placenta: a systematic review and meta-analysis. J Matern Fetal Neonatal Med. 2020;33:471-81.

9. Gao L, Huang Z, Zhang X, Zhou N, Huang X, Wang X. Reproductive outcomes following cesarean scar pregnancy - a case series and review of the literature. Eur J Obstet Gynecol Reprod Biol. 2016; 200: 102-7.

10. Timor-Tritsch IE, Khatib N, Monteagudo A, Ramos J, Berg R, Kovács S. Cesarean scar pregnancies: experience of 60 cases. J Ultrasound Med. 2015;34:601-10.

11. Ko JK, Li RH, Cheung VY. Cesarean scar pregnancy: a 10-year experience. Aust NZJ Obstet Gynaecol. 2015; 55:64-9.

12. Prisma statement. http://www.prisma-statement.org/ [accessed 10 March 2017]

This article is protected by copyright. All rights reserved 
13. Welch V, Petticrew M, Petkovic J, et al. PRISMA-Equity Bellagio group. Extending the PRISMA statement to equity-focused systematic reviews (PRISMA-E 2012): explanation and elaboration. J ClinEpidemiol. 2016;70:68-89.

14. Timor-Tritsch IE, Monteagudo A, Cali G, El Refaey H, Kaelin Agten A, Arslan AA. Easy sonographic differential diagnosis between intrauterine pregnancy and cesarean delivery scar pregnancy in the early first trimester. Am J Obstet Gynecol. 2016; 215 : 225.e1-7.

15. Newcastle-Ottawa Scale for assessing the quality of nonrandomised studies in metaanalyses. http://www.ohri.ca/programs/clinical_epidemiology/oxford.asp. [Accessed 1 March 2015]

16. HunterJP, SaratzisA, SuttonAJ, BoucherRH, SayersRD, BownMJ. In meta-analyses of proportion studies, funnel plots were found to be an inaccurate method of assessing publication bias. J Clin Epidemiol. 2014;67:897-903.

17. Higgins JPT, Chen S (eds). Cochrane Handbook for Systematic Reviews of Interventions Version 5.0.2 [updated September 2009]. The Cochrane Collaboration, 2009. http://www.cochrane-handbook.org [Accessed 1 March 2017].

18. Egger M, Davey Smith G, Schneider M, Minder C. Bias in meta-analysis detected by a simple, graphical test. BMJ 1997;315:629-34.

19. Rutter CM, Gatsonis CA. A hierarchical regression approach to meta-analysis of diagnostic test accuracy evaluations. Stat Med 2001; 20:2865-84.

20. Orhan A, Kasapoğlu I, Çetinkaya Demir B, Özerkan K, Duzok N, Uncu G. Different treatment modalities and outcomes in cesarean scar pregnancy: a retrospective analysis of 31 cases ina unıversity hospital. Ginekol Pol. 2019;90:291-307.

21. Ben Nagi J, Helmy S, Ofili-Yebovi D, Yazbek J, Sawyer E, Jurkovic D. Reproductive outcomes of women with a previous history of Cesarean scar ectopic pregnancies. Hum Reprod. 2007;22:2012-15.

22. Chen L, Xiao S, Zhu X, He S, Xue M. Analysis of the Reproductive Outcome of Patients with Cesarean Scar Pregnancy Treated by High-Intensity Focused Ultrasound and Uterine Artery Embolization: A Retrospective Cohort Study. J Minim Invasive Gynecol. 2019;26:883-90.

23. Chiang YC, Tu YA, Yang JH, Lin SY, Lee CN, Shih JC. Risk factors associated with failure of treatment for cesarean scar pregnancy. Int J Gynecol Obstet. 2017;138:28-36.

This article is protected by copyright. All rights reserved 
24. de Vaate AJ, Brölmann HA, van der Slikke JW, Wouters MG, Schats R, Huirne JA. Therapeutic options of cesarean scar pregnancy: case series and literature review. J Clin Ultrasound. 2010;38:75-84. 
25. Donnez O, Donnez J, Orellana R, Dolmans MM. Gynecological and obstetrical outcomes after laparoscopic repair of a cesarean scar defect in a series of 38 women. Fertil Steril. 2017;107:289-296.e2.

26. Du YJ, Zhang XH, Wang LQ. Risk Factors for Hemorrhage during Suction Curettage after Uterine Artery Embolization for Treating Cesarean Scar Pregnancy: A CaseControl Study. Gynecol Obstet Invest. 2015;80:259-64.

27. Elmokadem AH, Abdel-Wahab RM, El-Zayadi AA, Elrakhawy MM. Uterine Artery Embolization and Methotrexate Infusion as Sole Management for Cesarean Scar and Cervical Ectopic Pregnancies: A Single-Center Experience and Literature Review. Can Assoc Radiol J. 2019;70:307-16.

28. Grechukhina O, Deshmukh U, Fan L, et al. Cesarean Scar Pregnancy, Incidence, and Recurrence: Five-Year Experience at a Single Tertiary Care Referral Center. Obstet Gynecol. 2018;132:1285-95.

29. Halperin R, Schneider D, Mendlovic S, Pansky M, Herman A, Maymon R. Uterinepreserving emergency surgery for cesarean scar pregnancies: another medical solution to an iatrogenic problem. Fertil Steril. 2009;91:2623-7.

30. He Y, Wu X, Zhu Q, et al. Combined laparoscopy and hysteroscopy vs. uterine curettage in the uterine artery embolization-based management of cesarean scar pregnancy: a retrospective cohort study. BMC Womens Health. 2014;14:116.

31. Jabeen K, Karuppaswamy J. Non-surgical management of cesarean scar ectopic pregnancy - a five-year experience. J Obstet Gynecol. 2018;38:1121-27.

32. Karahasanoglu A, Uzun I, Deregözü A, Ozdemir M. Successful Treatment of Cesarean Scar Pregnancy With Suction Curettage: Our Experiences in Early Pregnancy. Ochsner J. 2018;18:222-5.

33. Lan W, Hu D, Li Z, Wang L, Yang W, Hu S. Bilateral uterine artery chemoembolization combined with dilation and curettage for treatment of cesarean scar pregnancy: A method for preserving the uterus. J Obstet Gynecol Res. 2013;39:1153-58.

34. Le A, Shan L, Xiao T, Zhuo R, Xiong H, Wang Z. Transvaginal surgical treatment of cesarean scar ectopic pregnancy. Arch Gynecol Obstet. 2013;287:791-6.

35. Le A, Li M, Xu Y, et al. Different Surgical Approaches to 313 Cesarean Scar Pregnancies. J Minim Invasive Gynecol. 2019;26:148-52. 
36. Li JB, Kong LZ, Fan L, Fu J, Chen SQ, Yao SZ. Transvaginal surgical management of cesarean scar pregnancy: analysis of 49 cases from one tertiary care center. . Eur J Obstet Gynecol Reprod Biol. 2014;182:102-6.

This article is protected by copyright. All rights reserved 
37. Li YY, Yin ZY, Li S, et al. Comparison of transvaginal surgery and methotrexate/mifepristone-combined transcervical resection in the treatment of cesarean scar pregnancy. Eur Rev Med Pharmacol Sci. 2017;21:2957-63.

38. Lian F, Wang Y, Chen W, et al. Uterine artery embolization combined with local methotrexate and systemic methotrexate for treatment of cesarean scar pregnancy with different ultrasonographic pattern. J Cardiovasc Intervent Radiol. 2012;35:286-91.

39. Lu YM, Guo YR, Zhou MY, Wang Y. Indwelling Intrauterine Foley Balloon Catheter for Intraoperative and Postoperative Bleeding in Cesarean Scar Pregnancy. J Minim Invasive Gynecol. 2020;27:94-9.

40. Maymon R, Svirsky R, Smorgick N, et al. Fertility performance and obstetric outcomes among women with previous cesarean scar pregnancy.J Ultrasound Med. 2011;30:1444.

41. Michener C, Dickinson JE, Aust N Z. Cesarean scar ectopic pregnancy: a single centre case series. J Obstet Gynecol. 2009;49:451-5

42. Osada H, Teramoto S, Kaijima H, et al. J A Novel Treatment for Cervical and Cesarean Section Scar Pregnancies by Transvaginal Injection of Absolute Ethanol to Trophoblasts: Efficacy in 19 Cases. Minim Invasive Gynecol. 2019;26:129-34.

43. Qi F, Zhou W, Wang MF, Chai ZY, Zheng LZ. Uterine artery embolization with and without local methotrexate infusion for the treatment of cesarean scar pregnancy. Taiwan J Obstet Gynecol. 2015;54:376-80.

44. Qi F, Chai ZY, Liu MM, et al. Type 2 Cesarean Scar Pregnancy Successfully Treated via Hysteroscopy-Assisted Laparoscopy. J Minim Invasive Gynecol. 2019;26:1273-81.

45. Qiu J, Fu Y, Xu J, Huang X, Yao G, Lu W. Analysis on clinical effects of dilation and curettage guided by ultrasonography versus hysteroscopy after uterine artery embolization in the treatment of cesarean scar pregnancy. Ther Clin Risk Manag. 2019;15:83-9.

46. Seow KM, Hwang JL, Tsai YL, Huang LW, Lin YH, Hsieh BC. Subsequent pregnancy outcome after conservative treatment of a previous cesarean scar pregnancy. Acta Obstet Gynecol Scand. 2004;83:1167-72.

47. Shen L, Tan A, Zhu H, Guo C, Liu D, Huang W. Bilateral uterine artery chemoembolization with methotrexate for cesarean scar pregnancy. Am J Obstet Gynecol. 2012;207:386.e1-6.

This article is protected by copyright. All rights reserved 
48. Smorgick N, Vaknin Z, Pansky M, Halperin R, Herman A, Maymon R. Combined local and systemic methotrexate treatment of viable ectopic pregnancy: outcomes of 31 cases. J Clin Ultrasound. 2008;36:545-50.

49. Sun QL, Wu XH, Luo L, Ying DM, Yang Y, Chen ZQ. Characteristics of women with mixed mass formation after evacuation following uterine artery chemoembolization for cesarean scar pregnancy. Arch Gynecol Obstet. 2018;297:1059-66.

50. Tumenjargal A, Tokue H, Kishi H, Hirasawa H, Taketomi-Takahashi A, Tsushima Y. Uterine Artery Embolization Combined with Dilation and Curettage for the Treatment of Cesarean Scar Pregnancy: Efficacy and Future Fertility. Cardiovasc Intervent Radiol. 2018;41:1165- 73 .

51. Uludag SZ, Kutuk MS, Ak M, et al. Comparison of systemic and local methotrexate treatments in cesarean scar pregnancies: time to change conventional treatment and follow-up protocols. Eur J Obstet Gynecol Reprod Biol. 2016;206:131-5.

52. Uysal F, Uysal A, Adam G. Cesarean scar pregnancy: diagnosis, management, and follow- up. J Ultrasound Med. 2013;32:1295-1300.

53. Wang YQ, Yin TL, Xu WM, Qi QR, Wang XC, Yang J. Reproductive outcomes in women with prior cesarean section undergoing in vitro fertilization: A retrospective case-control study. J Huazhong Univ Sci Technolog Med Sci. 2017;37:922-7.

54. Washburn EE, Pocius K, Carusi D. Outcomes of nonsurgical versus surgical treatment of cesarean scar pregnancies in the first trimester. Arch Gynecol Obstet. 2017;296:53341.

55. Yang XY, Yu H, Li KM, Chu YX, Zheng A. Uterine artery embolisation combined with local methotrexate for treatment of cesarean scar pregnancy. BJOG. 2010;117:990-6.

56. Yang G, Lee D, Lee S, Jeong K. Successful live births after surgical treatments for symptomatic cesarean scar pregnancies: report of 3 cases. Gynecol Obstet Invest. 2014;78:208-12.

57. Zhang Y, Duan H, Cheng JM, Guo YS. Treatment options to terminate persistent cesarean scar pregnancy. Gynecol Obstet Invest. 2013;75:115-19.

58. Zhang C, Liu G, Guo Q, Li Y, Yang Q. Foley Catheter-Assisted Laparoscopic Treatment of Type II Cesarean Scar Pregnancy. J Minim Invasive Gynecol. 2016;23:639-42.

59. Zhang C, Zhang Y, He J, Zhang L. Outcomes of subsequent pregnancies in patients 
following treatment of cesarean scar pregnancy with high intensity focused ultrasound followed by ultrasound-guided dilation and curettage. Int J Hyperthermia. 2019;36:92631.

This article is protected by copyright. All rights reserved 
60. Li Y, Lu L, Wang W, Sun J, Zhang X, Huang X. Retrospective study of patients with cesarean scar pregnancies treated by uterine artery chemoembolization and curettage. Int J Gynecol Obstet. 2018;143:172-177.

61. Keag OE, Norman JE, Stock SJ. Long-term risks and benefits associated with cesarean delivery for mother, baby, and subsequent pregnancies: Systematic review and metaanalysis. PLoS Med. 2018;15 e1002494.

62. Morlando M, Ferrara L, D'Antonio F, et al. Dichorionic triplet pregnancies: risk of miscarriage and severe preterm delivery with fetal reduction versus expectant management. Outcomes of a cohort study and systematic review. BJOG. 2015;122(8):1053-60.

\section{Supporting Information legend}

Table S1: Excluded studies and reason for the exclusion.

\section{Figure legends}

Figure 1. Systematic review flowchart.

Figure 2. Pooled proportions for the occurrence of a new pregnancy, intra-uterine pregnancy and recurrence cesarean scar pregnancy after a prior cesarean scar pregnancy.

Figure 3. Hypothetical model of 1000 cesarean scar pregnancy (CSP) wanting to achieve a subsequent pregnancy. 
Table 1. General characteristics of the included studies. CSP, cesarean scar pregnancy.

\begin{tabular}{|c|c|c|c|c|c|c|c|c|}
\hline Author & Year & Country & Study design & $\begin{array}{c}\text { Period } \\
\text { considered }\end{array}$ & CSP treatment & Outcomes observed & CSP (n) & $\begin{array}{c}\text { Pregnancies aft } \\
\text { CSP (n) }\end{array}$ \\
\hline $\mathrm{Qiu}^{45}$ & 2019 & China & Retrospective & 2013-2018 & surgical & $\begin{array}{l}\text { Reproductive and pregnancy } \\
\text { outcome }\end{array}$ & 62 & 25 \\
\hline Zhang 59 & 2019 & China & Retrospective & $2015-2018$ & surgical & $\begin{array}{l}\text { Reproductive and pregnancy } \\
\text { outcome }\end{array}$ & 154 & 23 \\
\hline $\mathrm{Lu}^{39}$ & 2019 & China & Retrospective & $2015-2017$ & $\begin{array}{l}\text { surgical and/or } \\
\text { non- } \\
\text { surgical }\end{array}$ & $\begin{array}{l}\text { Reproductive and pregnancy } \\
\text { outcome }\end{array}$ & 70 & 2 \\
\hline Elmokadem $^{27}$ & 2019 & Egypt & Retrospective & NS & $\begin{array}{l}\text { surgical and/or } \\
\text { non- } \\
\text { surgical }\end{array}$ & pregnancy outcomes & 7 & 1 \\
\hline Orhan $^{20}$ & 2019 & Turkey & Retrospective & 2011-2017 & $\begin{array}{l}\text { surgical and/or } \\
\text { non- } \\
\text { surgical }\end{array}$ & pregnancy outcomes & 31 & 9 \\
\hline Chen $\mathrm{L}^{22}$ & 2018 & China & Retrospective & $2007-2016$ & surgical & $\begin{array}{l}\text { Reproductive and pregnancy } \\
\text { outcome }\end{array}$ & 617 & 103 \\
\hline Grechukhina ${ }^{28}$ & 2018 & USA & Retrospective & 2013-2018 & $\begin{array}{l}\text { surgical and/or } \\
\text { non- } \\
\text { surgical }\end{array}$ & pregnancy outcomes & 30 & 10 \\
\hline $\operatorname{Li~} Y^{60}$ & 2018 & China & Retrospective & $2006-2016$ & surgical & $\begin{array}{l}\text { Reproductive and pregnancy } \\
\text { outcome }\end{array}$ & 301 & 102 \\
\hline Sun $\mathrm{QL}^{49}$ & 2018 & China & Retrospective & 2012-2015 & surgical & pregnancy outcomes & 395 & 17 \\
\hline Tumenjargal 50 & 2018 & Japan & Retrospective & 2006-2017 & surgical & $\begin{array}{l}\text { Reproductive and pregnancy } \\
\text { outcome }\end{array}$ & 33 & 7 \\
\hline
\end{tabular}




\begin{tabular}{|c|c|c|c|c|c|c|c|c|}
\hline $\mathrm{Le}^{35}$ & 2018 & China & Retrospective & $2011-2016$ & surgical & pregnancy outcomes & 313 & 19 \\
\hline $\mathrm{Qi}^{44}$ & 2018 & China & Retrospective & NS & surgical & pregnancy outcomes & 8 & 2 \\
\hline Karahasanoglu ${ }^{32}$ & 2018 & Turkey & Retrospective & $2009-2013$ & surgical & pregnancy outcomes & 19 & 5 \\
\hline $\mathrm{Li}^{37}$ & 2018 & China & Retrospective & $2011-2015$ & surgical & $\begin{array}{l}\text { Reproductive and pregnancy } \\
\text { outcome }\end{array}$ & 54 & 8 \\
\hline Osada $^{42}$ & 2018 & Japan & Retrospective & $2002-2017$ & & pregnancy outcomes & 3 & 1 \\
\hline Jabeen $^{31}$ & 2018 & UK & Retrospective & $2012-2017$ & Non-surgical & pregnancy outcomes & 26 & 5 \\
\hline Washburn 54 & 2017 & USA & Retrospective & $2000-2012$ & surgical & pregnancy outcomes & 23 & 12 \\
\hline Chiang $^{23}$ & 2017 & Taiwan & Retrospective & $1994-2015$ & $\begin{array}{l}\text { surgical and/or } \\
\text { non- } \\
\text { surgical }\end{array}$ & pregnancy outcomes & 90 & 7 \\
\hline $\mathrm{Gao}^{9}$ & 2016 & China & Retrospective & $2009-2012$ & surgical & $\begin{array}{l}\text { Reproductive and pregnancy } \\
\text { outcome }\end{array}$ & 22 & 11 \\
\hline
\end{tabular}




\begin{tabular}{|c|c|c|c|c|c|c|c|c|}
\hline Donnez $^{25}$ & 2016 & Belgium & $\begin{array}{l}\text { Retrospecti } \\
\text { ve }\end{array}$ & NS & surgical & $\begin{array}{l}\text { Reproductive and } \\
\text { pregnancy } \\
\text { outcome }\end{array}$ & 38 & 8 \\
\hline Uludag 51 & 2016 & Turkey & $\begin{array}{l}\text { Retrospecti } \\
\text { ve }\end{array}$ & $2000-2015$ & Non-surgical & $\begin{array}{r}\text { Reproductive and } \\
\text { pregnancy } \\
\text { outcome }\end{array}$ & 44 & 27 \\
\hline Zhang 58 & 2016 & China & $\begin{array}{l}\text { Retrospecti } \\
\text { ve }\end{array}$ & 2013-2014 & surgical & pregnancy outcomes & 8 & 1 \\
\hline Wang $\mathrm{YQ}^{53}$ & 2015 & China & $\begin{array}{l}\text { Retrospecti } \\
\text { ve }\end{array}$ & $\begin{array}{l}203809- \\
2013\end{array}$ & surgical & $\begin{array}{r}\text { Reproductive and } \\
\text { pregnancy } \\
\text { outcome }\end{array}$ & 189 & 32 \\
\hline $\mathrm{Ko}^{11}$ & 2015 & Hong Kong & $\begin{array}{l}\text { Retrospecti } \\
\text { ve }\end{array}$ & $2004-2013$ & $\begin{array}{l}\text { surgical and/or } \\
\text { non- } \\
\text { surgical }\end{array}$ & pregnancy outcomes & 22 & 4 \\
\hline $\mathrm{Du}^{26}$ & 2015 & China & $\begin{array}{l}\text { Retrospecti } \\
\text { ve }\end{array}$ & $2006-2012$ & surgical & $\begin{array}{l}\text { Reproductive and } \\
\text { pregnancy } \\
\text { outcome }\end{array}$ & 35 & 11 \\
\hline $\begin{array}{l}\text { Timor- } \\
\text { Tritsch } 10\end{array}$ & 2015 & $\begin{array}{l}\text { United } \\
\text { States }\end{array}$ & $\begin{array}{l}\text { Retrospecti } \\
\text { ve }\end{array}$ & 2009-2018 & Non-surgical & $\begin{array}{l}\text { Reproductive and } \\
\text { pregnancy } \\
\text { outcome }\end{array}$ & 96 & 32 \\
\hline $\mathrm{Qi}^{43}$ & 2015 & China & $\begin{array}{l}\text { Retrospecti } \\
\text { ve }\end{array}$ & $2009-2013$ & surgical & pregnancy outcomes & 50 & 4 \\
\hline Yang $\mathrm{G}^{56}$ & 2014 & South & Retrospecti & NS & surgical & Reproductive and & 3 & 4 \\
\hline
\end{tabular}




\begin{tabular}{|c|c|c|c|c|c|c|c|c|}
\hline & & Korea & ve & & & $\begin{array}{l}\text { pregnancy } \\
\text { outcome }\end{array}$ & & \\
\hline $\mathrm{Li}^{36}$ & 2014 & China & $\begin{array}{l}\text { Retrospecti } \\
\text { ve }\end{array}$ & $2009-2013$ & $\begin{array}{l}\text { surgical and/or } \\
\text { non- } \\
\text { surgical }\end{array}$ & pregnancy outcomes & 49 & 4 \\
\hline $\mathrm{He}^{30}$ & 2014 & China & $\begin{array}{l}\text { Retrospecti } \\
\text { ve }\end{array}$ & $2005-2019$ & surgical & $\begin{array}{l}\text { Reproductive and } \\
\text { pregnancy } \\
\text { outcome }\end{array}$ & 58 & 5 \\
\hline $\mathrm{Le}^{34}$ & 2013 & China & $\begin{array}{l}\text { Retrospecti } \\
\text { ve }\end{array}$ & $2008-2012$ & surgical & pregnancy outcomes & 38 & 3 \\
\hline $\operatorname{Lan}^{33}$ & 2013 & China & $\begin{array}{l}\text { Retrospecti } \\
\text { ve }\end{array}$ & $2004-2010$ & surgical & $\begin{array}{l}\text { Reproductive and } \\
\text { pregnancy } \\
\text { outcome }\end{array}$ & 79 & 16 \\
\hline Uysal $^{52}$ & 2013 & Turkey & $\begin{array}{l}\text { Retrospecti } \\
\text { ve }\end{array}$ & NS & $\begin{array}{l}\text { surgical and/or } \\
\text { non- } \\
\text { surgical }\end{array}$ & pregnancy outcomes & 7 & 2 \\
\hline Zhang 57 & 2012 & China & $\begin{array}{l}\text { Retrospecti } \\
\text { ve }\end{array}$ & $2005-2011$ & surgical & pregnancy outcomes & 10 & 4 \\
\hline $\operatorname{Lian}^{38}$ & 2012 & China & $\begin{array}{l}\text { Retrospecti } \\
\text { ve }\end{array}$ & $2005-2009$ & Non-surgical & pregnancy outcomes & 21 & 5 \\
\hline Shen 47 & 2012 & China & $\begin{array}{l}\text { Retrospecti } \\
\text { ve }\end{array}$ & $2008-2010$ & surgical & pregnancy outcomes & 46 & 2 \\
\hline Maymon $^{40}$ & 2011 & Israel & Retrospecti & $2000-2009$ & surgical and/or & Reproductive and & 432 & 8 \\
\hline
\end{tabular}




\begin{tabular}{|c|c|c|c|c|c|c|c|c|}
\hline & & & ve & & $\begin{array}{l}\text { non- } \\
\text { surgical }\end{array}$ & $\begin{array}{l}\text { pregnancy } \\
\text { outcome }\end{array}$ & & \\
\hline Yang $X^{55}$ & 2010 & China & $\begin{array}{l}\text { Retrospecti } \\
\text { ve }\end{array}$ & $2003-2008$ & surgical & pregnancy outcomes & 43 & 6 \\
\hline De Vaate 24 & 2010 & Holland & $\begin{array}{l}\text { Retrospecti } \\
\text { ve }\end{array}$ & $1996-2007$ & $\begin{array}{l}\text { surgical and/or } \\
\text { non- } \\
\text { surgical }\end{array}$ & pregnancy outcomes & 4 & 3 \\
\hline Michener 41 & 2009 & Australia & $\begin{array}{l}\text { Retrospecti } \\
\text { ve }\end{array}$ & $2002-2007$ & $\begin{array}{l}\text { surgical and/or } \\
\text { non- } \\
\text { surgical }\end{array}$ & pregnancy outcomes & 13 & 4 \\
\hline Halperin 29 & 2009 & Israel & $\begin{array}{l}\text { Retrospecti } \\
\text { ve }\end{array}$ & $2002-2007$ & surgical & pregnancy outcomes & 6 & 1 \\
\hline
\end{tabular}




\begin{tabular}{|c|c|c|c|c|c|c|c|c|}
\hline Smorgick $^{48}$ & 2008 & Israel & Retrospective & $2000-2006$ & Non-surgical & $\begin{array}{l}\text { Reproductive and pregnancy } \\
\text { outcome }\end{array}$ & 5 & 3 \\
\hline Ben Nagi ${ }^{21}$ & 2007 & UK & Retrospective & 1999-2005 & $\begin{array}{l}\text { surgical and/or non- } \\
\text { surgical }\end{array}$ & $\begin{array}{c}\text { Reproductive and pregnancy } \\
\text { outcome }\end{array}$ & 29 & 21 \\
\hline Seow 46 & 2004 & Taiwan & Retrospective & $1995-2002$ & $\begin{array}{l}\text { surgical and/or non- } \\
\text { surgical }\end{array}$ & pregnancy outcomes & 15 & 8 \\
\hline
\end{tabular}

CSP, cesarean scar pregnancy. 
Table 2. Quality assessment of the included studies according to Newcastle-Ottawa Scale (NOS) for case-control study. According to Newcastle-Ottawa Scale, a study can be awarded a maximum of one star for each numbered item within the Selection and Outcome categories. A maximum of two stars can be given for Comparability.

\begin{tabular}{|c|c|c|c|c|}
\hline Author & Year & Selection & Comparability & Outcome \\
\hline $\mathrm{Qiu}^{58}$ & 2019 & $\star \star \star$ & $\star$ & $\star \star$ \\
\hline Zhang 59 & 2019 & $\star \star$ & $\star$ & $\star \star$ \\
\hline $\mathrm{Lu}^{39}$ & 2019 & $\star \star$ & $\star$ & $\star \star$ \\
\hline Elmokadem ${ }^{27}$ & 2019 & $\star \star$ & $\star$ & $\star \star$ \\
\hline Orhan $^{20}$ & 2019 & $\star \star$ & $\star$ & $\star \star$ \\
\hline Chen $\mathrm{L}^{22}$ & 2018 & $\star \star$ & $\star$ & $\star \star$ \\
\hline Grechukhina $^{28}$ & 2018 & $\star \star \star$ & $\star$ & $\star \star$ \\
\hline Li $Y^{60}$ & 2018 & $\star \star$ & $\star$ & $\star \star$ \\
\hline Sun $\mathrm{QL}^{48}$ & 2018 & $\star \star$ & $\star$ & $\star \star$ \\
\hline Tumenjargal $^{50}$ & 2018 & $\star \star$ & $\star$ & $\star \star$ \\
\hline $\mathrm{Le}^{35}$ & 2018 & $\star \star$ & $\star$ & $\star \star$ \\
\hline $\mathrm{Qi}^{44}$ & 2018 & $\star \star$ & $\star$ & $\star \star$ \\
\hline Karahasanoglu 32 & 2018 & $\star \star \star$ & $\star$ & $\star \star$ \\
\hline $\mathrm{Li}^{37}$ & 2018 & $\star \star$ & $\star$ & $\star \star$ \\
\hline Osada $^{42}$ & 2018 & $\star \star$ & $\star$ & $\star \star$ \\
\hline Jabeen $^{31}$ & 2018 & $\star \star$ & $\star$ & $\star \star$ \\
\hline Washburn ${ }^{54}$ & 2017 & $\star \star$ & $\star$ & $\star \star$ \\
\hline Chiang 23 & 2017 & $\star \star$ & $\star$ & $\star \star$ \\
\hline $\mathrm{Gao}^{9}$ & 2016 & $\star \star \star$ & $\star$ & $\star \star$ \\
\hline
\end{tabular}




\begin{tabular}{|c|c|c|c|c|}
\hline Donnez 25 & 2016 & $\star \star$ & $\star$ & $\star \star$ \\
\hline Uludag 51 & 2016 & $\star \star$ & $\star$ & $\star \star$ \\
\hline Zhang $^{57}$ & 2016 & $\star \star$ & $\star$ & $\star \star$ \\
\hline Wang $Y_{Q} Q^{53}$ & 2015 & $\star \star$ & $\star$ & $\star \star$ \\
\hline $\mathrm{Ko}^{11}$ & 2015 & $\star \star$ & $\star$ & $\star \star$ \\
\hline $\mathrm{Du}^{26}$ & 2015 & $\star \star$ & $\star$ & $\star \star$ \\
\hline Timor-Tritsch ${ }^{10}$ & 2015 & $\star \star \star$ & $\star$ & $\star \star$ \\
\hline $\mathrm{Qi}^{43}$ & 2015 & $\star \star$ & $\star$ & $\star \star$ \\
\hline Yang $G^{56}$ & 2014 & $\star \star$ & $\star$ & $\star \star$ \\
\hline $\mathrm{Li}^{36}$ & 2014 & $\star \star$ & $\star$ & $\star \star$ \\
\hline $\mathrm{He}^{30}$ & 2014 & $\star \star$ & $\star$ & $\star \star$ \\
\hline $\mathrm{Le}^{34}$ & 2013 & $\star \star$ & $\star$ & $\star \star$ \\
\hline $\operatorname{Lan}^{33}$ & 2013 & $\star \star$ & $\star$ & $\star \star$ \\
\hline Uysal $^{52}$ & 2013 & $\star \star$ & $\star$ & $\star \star$ \\
\hline
\end{tabular}




\begin{tabular}{|c|c|c|c|c|}
\hline Zhang 56 & 2012 & $\star \star \star$ & $\star$ & $\star \star$ \\
\hline $\operatorname{Lian}^{38}$ & 2012 & $\star \star$ & $\star$ & $\star \star$ \\
\hline Shen $^{47}$ & 2012 & $\star \star$ & $\star$ & $\star \star$ \\
\hline Maymon $^{40}$ & 2011 & $\star \star$ & $\star$ & $\star \star$ \\
\hline Yang XY ${ }^{55}$ & 2010 & $\star \star$ & $\star$ & $\star \star$ \\
\hline De Vaate 27 & 2010 & $\star \star$ & $\star$ & $\star \star$ \\
\hline Michener 41 & 2009 & $\star \star$ & $\star$ & $\star \star$ \\
\hline Halperin $^{29}$ & 2009 & $\star \star$ & $\star$ & $\star \star$ \\
\hline Smorgick 48 & 2008 & $\star \star \star$ & $\star$ & $\star \star$ \\
\hline Ben Nagi 23 & 2007 & $\star \star$ & $\star$ & $\star \star$ \\
\hline Seow $^{46}$ & 2004 & $\star \star$ & $\star$ & $\star \star$ \\
\hline
\end{tabular}


Table 3. Pooled proportions for the outcomes explored in the present systematic review

\begin{tabular}{|l|c|l|l|c|c|}
\hline Outcome & $\begin{array}{c}\text { Studies } \\
(\mathbf{n})\end{array}$ & Cases (n) & Raw proportions (95\% CI) & $\mathbf{I}^{2}$ (\%) & Pooled proportions (95\% CI) \\
\hline Recurrence of CSP & 44 & $107 / 618$ & $17.31(14.4-20.5)$ & 47.7 & $17.14(14.3-20.2)$ \\
\hline Pregnancy after CSP & 18 & $300 / 425$ & $70.58(66.0-74.9)$ & 82.4 & $71.08(66.7-75.2)$ \\
\hline Intra-uterine pregnancy following CSP & 44 & $503 / 618$ & $812.39(78.1-84.4)$ & 49.8 & $81.62(78.5-84.5)$ \\
\hline Ectopic pregnancy & 44 & $8 / 618$ & $1.29(0.6-2.5)$ & 0 & $2.25(1.2-3.5)$ \\
\hline Uterine rupture & 33 & $5 / 341$ & $1.47(0.5-3.4)$ & 0 & $2.43(1.1-4.3)$ \\
\hline Miscarriage & 33 & $65 / 341$ & $19.06(15.0-23.6)$ & 29.9 & $19.37814 .2-25.1)$ \\
\hline Preterm birth & 26 & $25 / 243$ & $10.29(6.8-14.8)$ & 30.2 & $11.67(7.2-17.3)$ \\
\hline PAS disorders & 30 & $13 / 327$ & $3.98(2.1-6.7)$ & 0 & $4.93(2.9-7.5)$ \\
\hline Uncomplicated pregnancies & 30 & $219 / 327$ & $66.97(61.6-72.0)$ & 53.1 & $66.12(57.8-74.0)$ \\
\hline
\end{tabular}

a: only studies reporting the number of women wishing to conceive after a CSP, were included in the computation of this outcome.

CSP, cesarean scar pregnancy. PAS, placenta accreta spectrum. 
Table 4. Pooled proportions for the outcomes explored in the present systematic review in women with a prior cesarean scar pregnancy (CSP) undergoing surgical or non-surgical treatment.

\begin{tabular}{|c|c|c|c|c|c|}
\hline Outcome & Studies (n) & Cases (n) & $\begin{array}{c}\text { Raw proportions } \\
(95 \% \mathrm{CI})\end{array}$ & $\mathrm{I}^{2}(\%)$ & $\begin{array}{c}\text { Pooled proportions } \\
(95 \% \mathrm{CI})\end{array}$ \\
\hline & \multicolumn{5}{|c|}{ Surgical treatment } \\
\hline Recurrence of CSP & 27 & $90 / 428$ & $21.02(17.3-25.2)$ & 63 & $21.01(13.9-29.2)$ \\
\hline Pregnancy after CSP & 11 & $244 / 328$ & $74.39(69.3-79.0)$ & 72 & $72.23(60.6-82.5)$ \\
\hline Intra-uterine pregnancy following CSP & 27 & $331 / 428$ & $77.34(73.1-81.2)$ & 63 & $77.70(69.4-85.0)$ \\
\hline Ectopic pregnancy & 27 & $7 / 428$ & $1.64(0.6-3.3)$ & 0 & $2.38(1.2-4.0)$ \\
\hline Uterine rupture & 20 & $2 / 233$ & $0.86(0.1-3.1)$ & 0 & $1.84(0.5-3.9)$ \\
\hline Miscarriage & 21 & $38 / 234$ & $16.24(11.8-21.6)$ & 30.8 & $16.43(10.5-23.4)$ \\
\hline Preterm birth & 16 & $14 / 157$ & $8.92(5.0-14.5)$ & 0 & $9.71(5.7-14.79$ \\
\hline PAS disorders & 19 & $6 / 221$ & $2.71(1.0-5.8)$ & 0 & $4.00(1.9-6.9)$ \\
\hline \multirow[t]{2}{*}{ Uncomplicated pregnancy } & 19 & $143 / 221$ & $64.71(58.0-71.0)$ & 76.9 & $61.61(46.2-75.9)$ \\
\hline & \multicolumn{5}{|c|}{ Non-surgical treatment } \\
\hline Recurrence of CSP & 17 & $21 / 138$ & $15.22(9.7-22.4)$ & 63 & $15.65(6.3-28.2)$ \\
\hline Pregnancy after CSP & 5 & $46 / 67$ & $68.66(56.2-79.4)$ & 16.4 & $79.90(57.0-83.0)$ \\
\hline Intra-uterine pregnancy following CSP & 17 & $116 / 138$ & $84.06(76.9-89.7)$ & 63.1 & $82.96(70.1-92.8)$ \\
\hline Ectopic pregnancy & 17 & $1 / 138$ & $0.72(0.01-4.0)$ & 0 & $2.50(0.6-5.6)$ \\
\hline Uterine rupture & 13 & $3 / 68$ & $4.41(0.9-12.4)$ & 23 & $6.00(1.8-12.5)$ \\
\hline Miscarriage & 13 & $14 / 68$ & $14.71(7.3-25.4)$ & 0 & $21.41(12.9-31.4)$ \\
\hline Preterm birth & 11 & $10 / 66$ & $15.15(7.5-26.1)$ & 56.4 & $16.59(5.5-32.1)$ \\
\hline PAS disorders & 11 & $7 / 66$ & $10.61(4.4-20.6)$ & 0 & $12.04(5.6-20.5)$ \\
\hline Uncomplicated pregnancy & 11 & $42 / 66$ & $63.64(50.9-75.1)$ & 0 & $62.44(51.0-73.2)$ \\
\hline
\end{tabular}

PAS, placenta accreta spectrum. 


$$
(n=8)
$$

Records after duplicates removed

$$
(n=358)
$$

\section{Records screened}

$(n=358)$

Full-text articles assessed

for eligibility

$(n=122)$

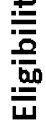

Studies included in

qualitative synthesis

$$
(n=44)
$$

$\frac{}{\frac{d}{0}}$

Studies included in

quantitative synthesis
Records excluded

$(n=236)$

Full-text articles excluded

with reasons

$(n=78)$

(meta-analysis)

$$
(n=44)
$$


Recurrence of CSP

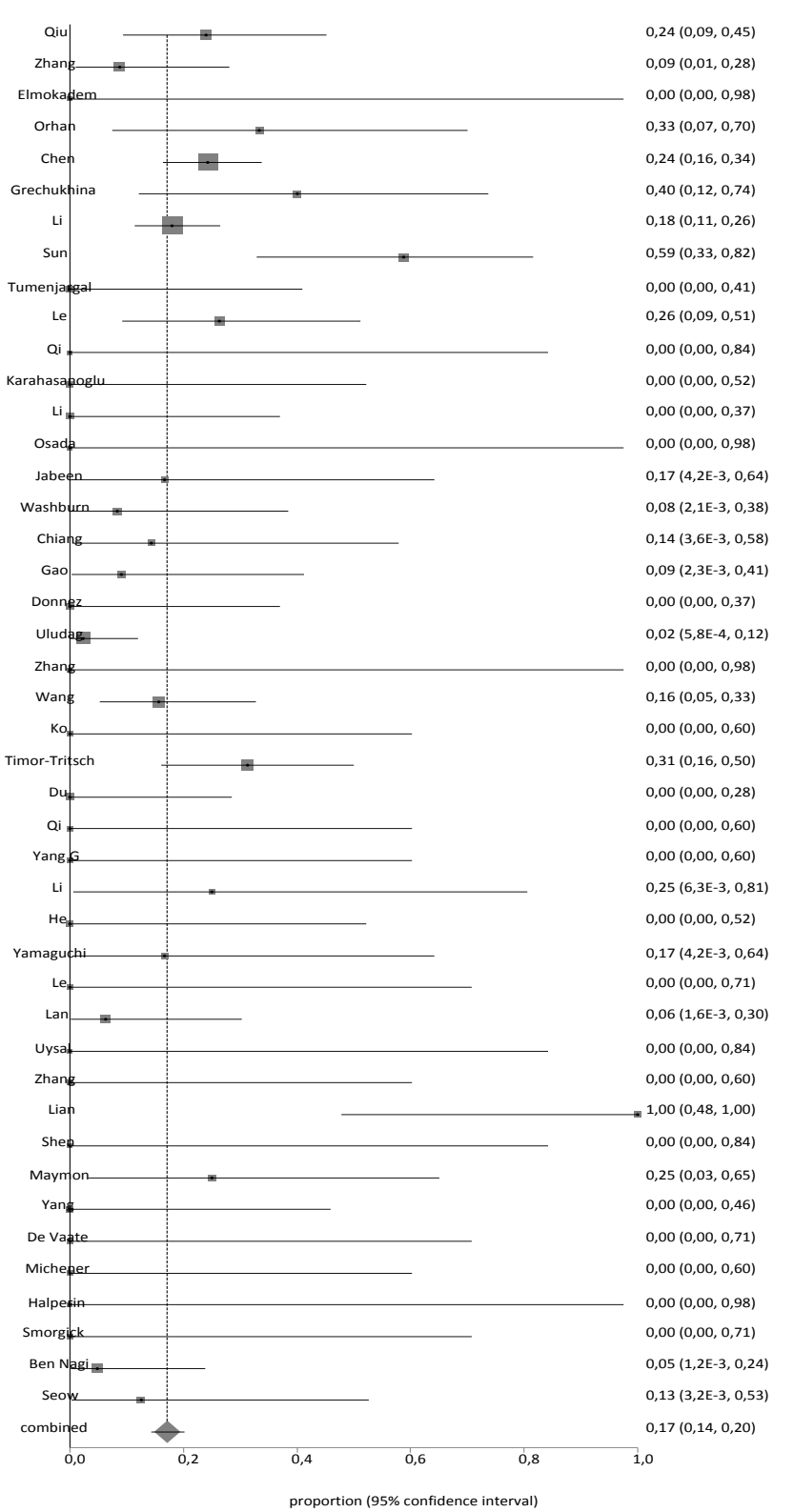


Women achieving pregnancy after CSP

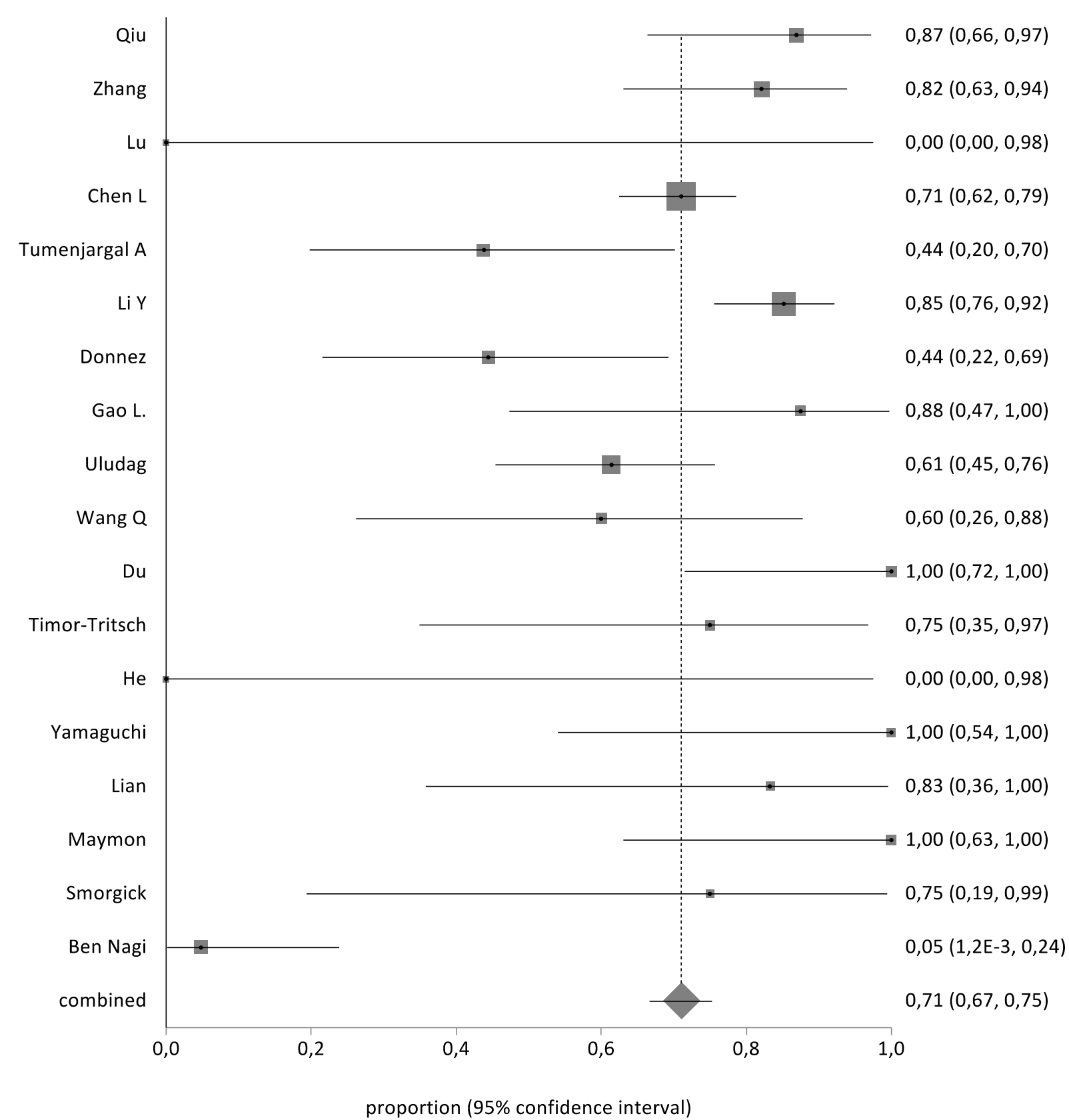


Figure 3 - Hypothetical model of 1000 CSP wanting to achieve a subsequent pregnancy.

\section{CSP treated medically or surgically wanting to conceive}

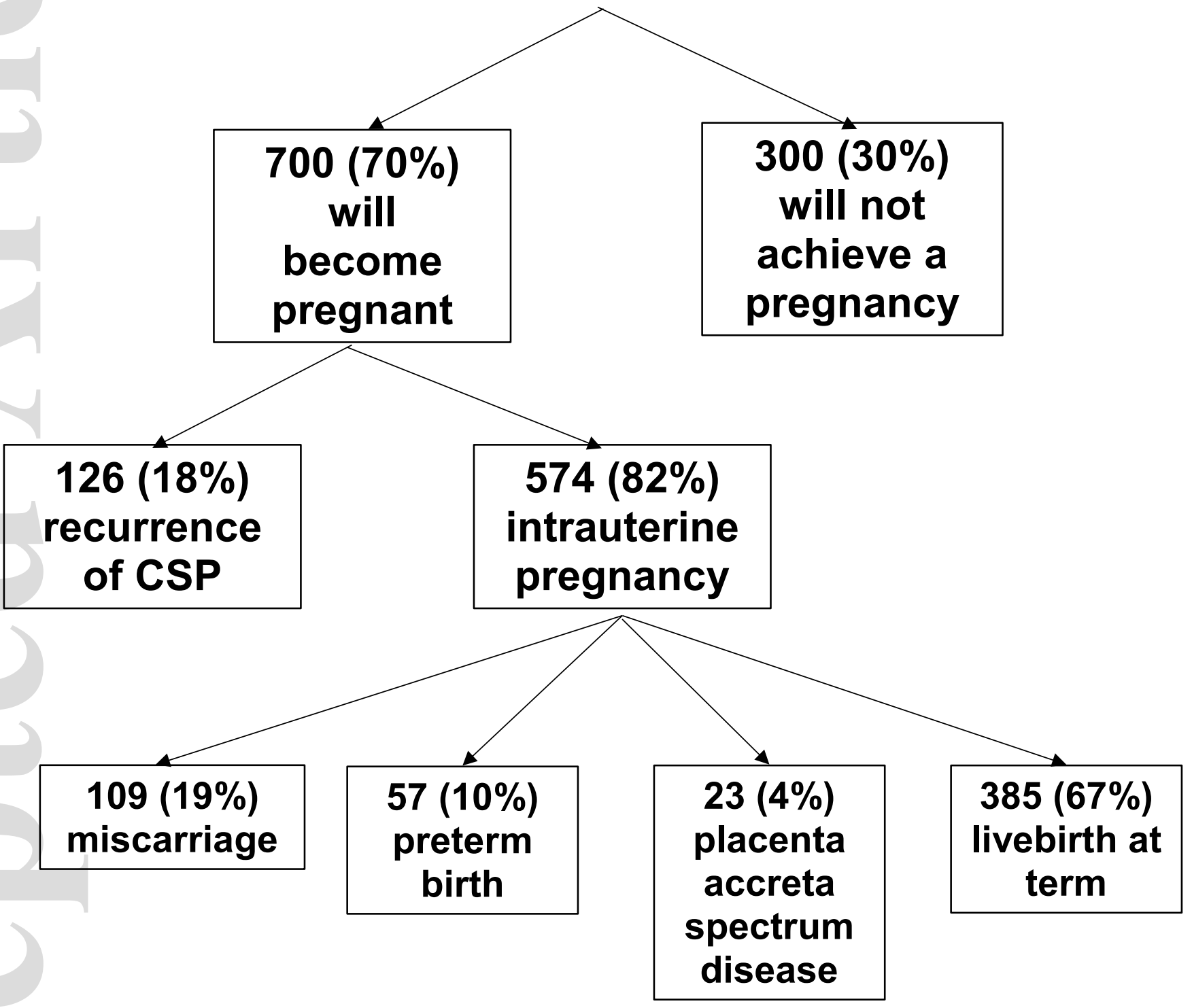

